\title{
Diazoxide-resistant hyperinsulinism
}

INSERM

\section{Source}

INSERM. (1999). Orphanet: an online rare disease and orphan drug data base. Diazoxideresistant hyperinsulinism. ORPHA:276585

Diazoxide-resistant hyperinsulism (DRH) is form of congenital isolated hyperinsulism (see this term) caused by an abnormal insulin production by b-cells in the pancreas that can be diffuse or focal and is characterized by an excessive/ uncontrolled insulin secretion (inappropriate for the level of glycemia), recurrent episodes of profound hypoglycemia and resistance to medical management with diazoxide. 